\title{
MECHANICAL PROPERTIES OF CEMENT COMPOSITE CONTAINING RECYCLED CONCRETE AND ALKALI ACTIVATED BLAST FURNACE SLAG
}

\author{
Jan Horych*, Pavel Tesárek, ZdenĚK ProšEK \\ Czech Technical University in Prague, Faculty of Civil Engineering, Department of Mechanics, Thákurova 7, \\ 16629 Prague 6, Czech Republic \\ * corresponding author: jan.horych@fsv.cvut.cz
}

\begin{abstract}
Recycling of materials is very popular and very important in these days. Finding the new ways to process and use these materials is a key to get rid of a lot of construction waste. The amount of landfilling needs to be reduced. This study observes mechanical properties of the cement composites containing recycled concrete powder and alkali-activated blast furnace slag processed on a high-speed mill as a potential binder replacement up to the $60 \mathrm{wt}$. \%. These materials have a positive effect on hydration process, increase flexural strength. It can reduce compressive strength loss when an amount of cement in the mixture is reduced.
\end{abstract}

KEYwords: Composites, waste, blast furnace slag, recycled concrete, cement matrix.

\section{INTRODUCTION}

According to the current recycling trend, we want to find a way to use waste material as a material to create something new. In this research we use recycled concrete and blast furnace slag to replace cement and reduce impact of its production. Cement is the most important but the most expensive ingredient in concrete. The production of cement is based on natural resources and its processing needs a lot of energy. Unfortunately, these used materials have their own issues and problems that have to be solved. Many studies are focused on similar topic [1-6]. Some of these studies are using blast furnace slag or recycled concrete to improve mechanical properties. The Canadian study [7] is similar to our research. It uses the blast furnace slag as a binder and examines all physical properties of concrete including workability, air content, elastic modulus, strength, shrinkage, durability and carbonation. The results of all test confirmed the opinion, that the blast furnace slag can be used as a binder. It has a positive effect on mechanical properties and durability of concrete. Another study 8 solves the issue of recycled concrete powder used as a binder. They also used the high-speed mill to activate the material. They created samples with varying cement and recycled concrete percentages and observed mechanical properties of the samples. Results of this study showed the possibility to use recycled concrete in practise. Concrete with cement and recycled concrete produce higher hydration heat. It is caused by unhydrated cement grains contained in recycled concrete powder. Research [9] was based on fly ash, blast furnace slag and recycled concrete aggregate. The study investigated compressive and tensile strengths, elastic modulus, coefficient of permeability and durability in chloride and sulphate solutions. Blast furnace slag had positive effect for a concrete with recycled aggregate and could reduce strength losses. Fly ash had worse results and was recommended for further testing before being used in practice. The study [10] was focused on creation of alkali-activated foamed concrete with part of ground granulated blast furnace slag. All samples were produced using a pre-formed foam with no filler or aggregate. The results revealed that foamed concrete with blast furnace slag has a potential to be used in practise. It had even better mechanical properties than foamed concrete only with Portland cement.

\section{MATERIALS AND SAMPLES}

Testing samples were composed of Portland cement CEM I 42.5 R from Radotín. Another component was the recycled concrete micronized by high-speed mill in collaboration with Lavaris corporation. The source of concrete is 100 years old construction concrete from the demolished building on Waltrovka in Prague. Another component was the blast furnace slag kept from Kladno. It is 100 years old air-cooled and carbonated slag stored on a heap and it's the waste from slag aggregate production. This kind of slag is not suitable as a concrete binder. It needs to be activated. We use the same high-speed mill to activate it, because the blast furnace slag had a slow reaction for a long period of time. All of the samples were $40 \times 40 \times 160$ $\mathrm{mm}$ and they were stored in water for 28 days. During this time we made tests to find dynamic modulus of elasticity using a non-destructive resonance method and at the end, we made destructive bending test and compresion test to figure out final strength. Samples contain 50 or 40 wt. \% of Portland cement, 50 wt. $\%$ of recycled concrete and changing share of blast furnace slag and slaked lime from 0 to 10 wt. \% (Ta- 


\begin{tabular}{cccccc}
\hline Mixtures & $\begin{array}{c}\text { Portland } \\
\text { cement [wt. \%] }\end{array}$ & $\begin{array}{c}\text { Recycled } \\
\text { concrete [wt. \%] }\end{array}$ & $\begin{array}{c}\text { Slaked } \\
\text { lime [wt. \%] }\end{array}$ & $\begin{array}{c}\text { Blast furnace } \\
\text { slag [wt. \%] }\end{array}$ & $\begin{array}{c}\text { Flow } \\
\text { expansion } \\
\text { test [cm] }\end{array}$ \\
\hline A & 50.0 & 50.0 & 0.0 & 0.0 & 22.0 \\
B & 40.0 & 50.0 & 0.0 & 10.0 & 21.2 \\
C & 40.0 & 50.0 & 2.5 & 7.5 & 19.0 \\
D & 40.0 & 50.0 & 5.0 & 5.0 & 19.0 \\
E & 40.0 & 50.0 & 7.5 & 2.5 & 18.0 \\
F & 40.0 & 50.0 & 10.0 & 0.0 & 17.3 \\
\hline
\end{tabular}

TABLE 1. Composition of individual samples.

ble 11. It also shows the results of flow expansiom test. The part of slaked lime changes the result even when the water coefficient $\mathrm{w} / \mathrm{b}$ is the same. The slaked lime is very finely ground and because of this fact, the mixture has a different consistency. The water coefficient $\mathrm{w} / \mathrm{b}$ is set to 0.4 .

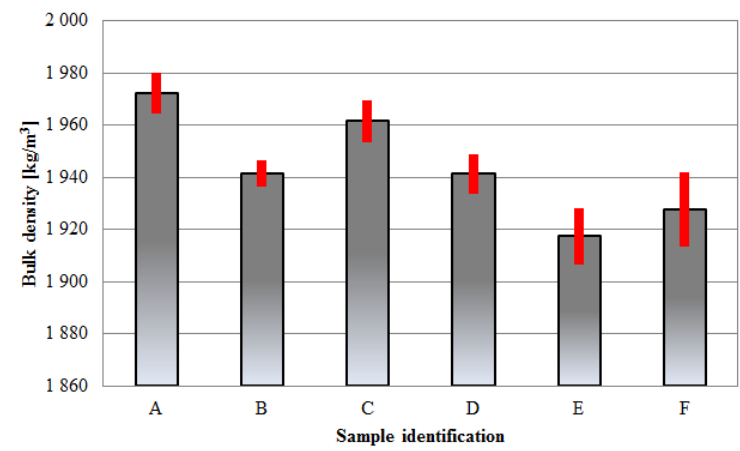

Figure 1. Final bulk density of the samples.

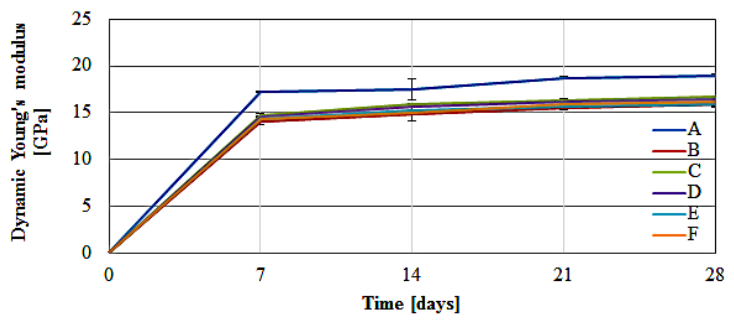

Figure 2. Development of the dynamic Young's modulus for the samples.

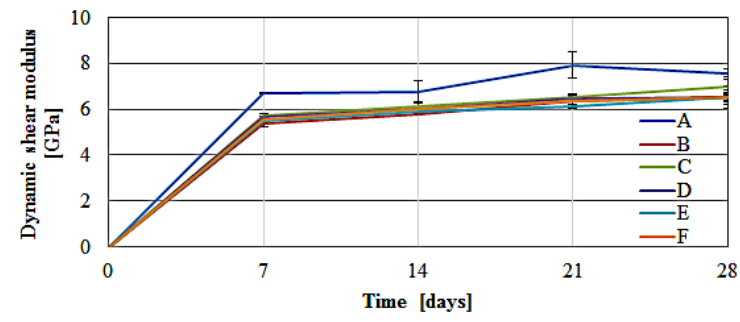

Figure 3. Development of the dynamic shear modulus for the samples.

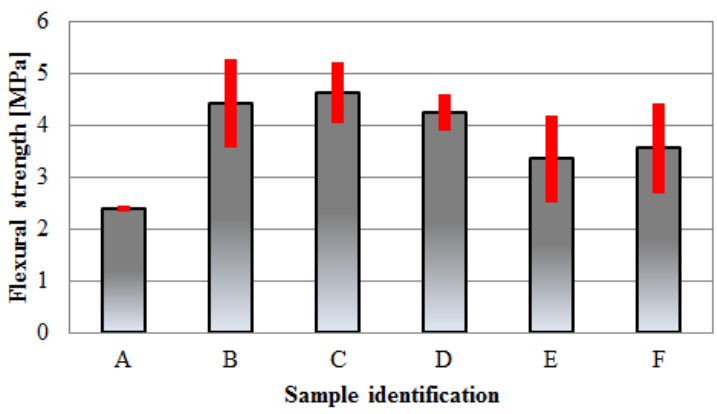

Figure 4. Flexural strength of the samples.

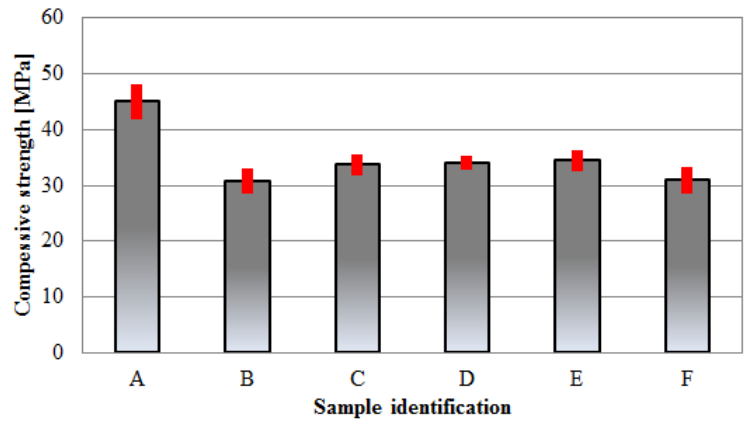

Figure 5. Compressive strength of the samples.

\section{Measurement methods}

During our research we measured dynamic Young's modulus, dynamic shear modulus, flexural and compressive strength. Dynamic Young's modulus and dynamic shear modulus were monitored using nondestructive resonance method during 28 days. The method is based on measuring the natural frequencies of longitudinal, transverse and torsional vibration of the samples. Samples were supported with a soft elastic pads at nodal points of basic natural mode shapes. Through the test we used Brüel \& Kjær measurement station type $3560-\mathrm{B}-\mathrm{X} 12$ to record the excitation and response signals. As an acceleration transducer was used Brüel \& Kjær type 4519-003 and another component is Brüel \& Kjær impact hammer type 8206 . Everything was connected to the computer with software PULSE LabShop. The excitation and response signals were transformed from the time domain to the 
frequency domain by using the Fast Fourier Transform. Frequency response function was calculated as a ratio of the response and the excitation force. The basic natural frequencies were evaluated with frequency response function and then were evaluated dynamic Young's modulus and dynamic shear modulus. In this method we also need to know the dimensions and the weight of the samples. [11, 12].

Flexural strength was measured on 28 days old samples using three-point bending test. The testing was displacement controlled at a constant rate of 1 $\mathrm{mm} / \mathrm{min}$ and the distance between supports of the sample was $100 \mathrm{~mm}$. During the test, samples were broken approximately in half. These halves $(40 \times$ $40 \times \sim 80 \mathrm{~mm}$ ) were used on the uniaxial compression test. The testing was displacement controlled at a rate of $5 \mathrm{~mm} / \mathrm{min}[13$.

\section{Results AND Discussion}

Figure 1 shows the final bulk density of all samples. The highest bulk density had the sample A as a reference. It had 50 wt. \% of Portland cement and $50 \mathrm{wt}$. $\%$ of recycled concrete powder. The second highest bulk density had the sample $\mathrm{C}$ with 40 wt. $\%$ of Portland cement, 50 wt. \% of recycled concrete powder, $7.5 \mathrm{wt}$. $\%$ of blast furnace slag and $2.5 \mathrm{wt}$. $\%$ of slaked lime as the activator.

As we can see in Figure 2 and Figure 3 sample $\mathrm{C}$ had also the highest dynamic Young's modulus and the dynamic shear modulus from the samples with 40 wt. \% of Portland cement. However the reference sample had the higher dynamic Young's modulus approximately by $3 \mathrm{GPa}$ and dynamic shear modulus by $1 \mathrm{GPa}$. Each sample was measured during 28 days every 7 days including its weight and dimensions. In both cases, dynamic Young's modulus and dynamic shear modulus had the highest progress in the first 7 days. Then the progress was much slower from day 7 to day 21 and in the last 7 days, the values were almost unchanged.

Figure 4 presents a flexural strength results of all samples. It is obvious that the blast furnace slag had a positive effect on flexural strength. The worst strength had a reference sample A without the slag. Samples B, C and D had a higher strength almost by $100 \%$. However, the highest strength had the sample $\mathrm{C}$ and confirmed the previous measurement.

Figure 5 shows the results of the compression test. It proved the effect of recycled concrete and slag. The highest compressive strength had a sample A because of the highest amount of cement in the mixture. As we can see, the samples C, D and E had approximately the same strength. The combination of blast furnace slag and slaked lime seemed to be effective.

Through all stages of testing, the results seemed very promisinig. It seemed that the most promising sample was sample $\mathrm{C}$ because of the highest flexural strength. Compressive strength was also one of the highest, so the ratio $3: 1$ of the slag and slaked lime seemed to be ideal. Recycled concrete could be used as a microfiller but, the study 6 , proved that very fine ground concrete has approximately $10 \%$ of unhydrated cement grains and these grains helps with hydration process. There is a need for more research, but used materials definitely have the potential to be used in practical applications.

\section{Conclusion}

This paper examined the recycled concrete powder and blast furnace slag as a cement replacement at the level of 60 wt. \% with various ratios of blast furnace slag and slaked lime and its effect on mechanical properties of samples. Based on the results, it can be concluded that:

- Amount of cement in concrete can be reduced without a massive loss of mechanical properties.

- Highly carbonated blast furnace slag can be used as a filler and also a binder with proper processing.

- Blast furnace slag had a very positive effect on flexural strength.

- The ratio 3:1 of blast furnace slag and slaked lime seems to be ideal.

\section{ACKNOWLEDGEMENTS}

This outcome was supported by the Czech Technical University in Prague under No. SGS19/148/OHK1/3T/11 and by Technology Agency of the Czech Republic (TA CR) research project TJ01000435, which is solved in cooperation with the company POZEMNÍ KOMUNIKACE BOHEMIA, a.s.. The authors also thank the Center for Nanotechnology in Civil Engineering at the Faculty of Civil Engineering, Czech Technical University in Prague.

\section{REFERENCES}

[1] S. Demirdag, L. Gunduz. Strength properties of volcanic slag aggregate lightweight concrete for high performance masonry units. Construction and Building Materials 22(3):135-142, 2008. DOI:10.1016/J.CONBUILDMAT.2006.10.002

[2] J. Sun, J. Feng, Z. Chen. Effect of ferronickel slag as fine aggregate on properties of concrete. Construction and Building Materials 206:201-209, 2019. DOI:10.1016/J.CONBUILDMAT.2019.01.187

[3] R. Arellano Aguilar, O. Burciaga Díaz, J. Escalante García. Lightweight concretes of activated metakaolinfly ash binders, with blast furnace slag aggregates. Construction and Building Materials 24(7):1166-1175, 2010. DOI:10.1016/J.CONBUILDMAT.2009.12.024.

[4] J. Schoon, K. De Buysser, I. Van Driessche, N. De Belie. Fines extracted from recycled concrete as alternative raw material for Portland cement clinker production. Cement and Concrete Composites 58:70-80, 2015. DOI:10.1016/J.CEMCONCOMP.2015.01.003

[5] J. Schoon, L. Van der Heyden, P. Eloy, et al. Waste fibrecement: An interesting alternative raw material for a sustainable Portland clinker production. Construction and Building Materials 36:391-403, 2012. DOI:10.1016/J.CONBUILDMAT.2012.04.095 
[6] Z. Prošek, J. Trejbal, J. Topič, et al. Utilization of the waste from the marble industry for application in transport infrastructure: Mechanical properties of cement pastes. IOP Conference Series: Materials Science and Engineering 236(1), 2017. DOI:10.1088/1757-899X/236/1/012092

[7] R. D. Hooton. Canadian use of ground granulated blast-furnace slag as a supplementary cementing material for enhanced performance of concrete. Canadian Journal of Civil Engineering 27(4):754-760, 2011. DOI:10.1139/100-014

[8] J. Topič, Z. Prošek. Properties and microstructure of cement paste including recycled concrete powder. Acta Polytechnica 57(1):49-57, 2017. DOI:10.14311/AP.2017.57.0049.

[9] M. L. Berndt. Properties of sustainable concrete containing fly ash, slag and recycled concrete aggregate.
Construction and Building Materials 23(7):2606-2613, 2009. DOI:10.1016/j.conbuildmat.2009.02.011

[10] K.-H. Yang, K.-H. Lee, J.-K. Song, M.-H. Gong. Properties and sustainability of alkali-activated slag foamed concrete. Journal of Cleaner Production 68:226233, 2014. DOI:10.1016/J.JCLEPRO.2013.12.068

[11] ASTM 1876-01. Standard Test Method for Dynamic Young's Modulus, Shear Modulus, and Poisson's Ratio by Impulse Excitation of Vibration, Annual Book of ASTM Standards, American Society for Testing and Materials 2006.

[12] ČSN 73 1372. In Nedestruktivní zkoušení betonu Rezonanční metoda zkoušení betonu, Úřd pro technickou normalizaci, metrologii a státní zkuševnictví, 2012.

[13] ČSN EN 12390 (731302). In Zkoužení ztvrdlého betonu. 2013. 